\title{
ARTICLES
}

\section{A BRIEF INTRODUCTION TO MEDICARE AND THE OFFICE OF MEDICARE HEARINGS AND APPEALS}

\section{Woody R. Clermont}

\section{INTRODUCTION}

Medicare is a single-payer federal program providing health insurance for individuals ages 65 and older, those meeting the definition for permanent disability within the Social Security Act, ${ }^{1}$ and those with end-stage renal disease. ${ }^{2}$ Medicare also covers care that is both reasonable and necessary in

* Woody R. Clermont, is an Assistant General Counsel, with the Office of the General Counsel for the Eleventh Judicial Circuit of Florida. The author's views are not necessarily those of the Office of the General Counsel. He received his J.D. from the University of Miami, his B.A. from Binghamton University, and his A.S. from the State University of New York at Empire State College. The author wishes to thank William P. VanderWyden III, Associate Dean of Students at the University of Miami School of Law, and I would especially like to thank Tina P. Smith for her invaluable wisdom and support, which helped to make this endeavor possible. Nonetheless, the author takes full responsibility for any errors, misstatements, or artless rhetoric.

1. The Social Security Act defines "disability" as the "inability to engage in any substantial gainful activity by reason of any medically determinable physical or mental impairment which can be expected to result in death or has lasted or can be expected to last for a continuous period of not less than 12 months." 42 U.S.C. § 223(d)(1) (2006). For purposes of confirming this disability, there is a five-step inquiry that requires: (1) that the claimant is not engaging in "substantial gainful activity"; and (2) the claimant has a "severe impairment"; and (3) the impairment meets the criteria of one of the "listing impairments"; or (4) considering the claimant's "residual functional capacity," the claimant is unable to do "past relevant work"; and (5) other work within the claimant's "residual functional capacity" does not exist in the national economy in significant numbers. 42 U.S.C. $\S 223(\mathrm{~d})(2)(\mathrm{A})$.

2. $\quad 42$ U.S.C. $\S 1395 \mathrm{rr}(2006) ; 42$ C.F.R. $\S \S 405,441.40$ (2010). 
connection with the diagnosis and treatment of the underlying illness or injury. ${ }^{3}$ Medicare evolved from the Social Security Act over the course of three decades. The original Social Security $\mathrm{Act}^{4}$ was drafted between 1934 and 1935 by the Committee on Economic Security; ${ }^{5}$ the Committee during the first term of President Franklin Delano Roosevelt's presidency, had been under the oversight of United States Secretary of Labor Frances Perkins. ${ }^{6}$

\section{A. The History of the Act}

President Roosevelt signed the act into law on August 14, $1935 .{ }^{7}$ President Roosevelt advocated the Social Security Act as a protection for the elderly under New Deal policies, during a time when poverty rates among the elderly were high. The original Act provided benefits to those retiring and those were unemployed, and it also provided for a lump-sum benefit at death; a shared payroll tax was imposed on employers and employees to finance the benefits. However, Roosevelt left medical health benefits out of the Act, fearful that the American public was not ready for national health care. ${ }^{8}$ It was not until decades later, through the Great Society domestic policy of President Lyndon Baines Johnson, which an extremely limited form of nationalized health insurance coverage, which applied only to a very narrow class of beneficiaries, would finally come to fruition.

As a part of President Johnson's Great Society initiative, Medicare, as well as Medicaid, were created by the Social Security Amendments of 1965 and signed into law on July 30, 1965. After signing the bill into law, Johnson handed the pens he used to sign the bill, to former President Harry S. Truman,

3. $\quad 42$ U.S.C. $\S 1395 y(a)(1)(A)$.

4. Social Security Act, Pub. L. No. 74-271, 49 Stat. 620 (1935).

5. Herbert Vetter, Notable American Unitarians 1936-1961, at 90-91 (Herbert Vetter ed., 2007) (noting that Thomas H. Eliot, Assistant Solicitor under Perkins, is credited with having a large part in drafting the Act).

6. Kristen Downey, The Woman Behind the New Deal: The Life of Frances Perkins 270 (First Anchor Books ed., Random House Inc. 2010) (2009). Frances Perkins was the first female ever appointed to a United States Cabinet position. She was a close friend to President Roosevelt and a loyal supporter. Of his original U.S. Cabinet members, she was only one of two, to remain at her post during Roosevelt's entire presidency.

7. Steven Green Livingston, United States Social Security: A Reference Handbook 11 (ABC-CLIO 2008).

8. Theda Skocpol, Is the Time Finally Ripe? Health Insurance Reforms in the 1990s, in THE Politics of Health Care Reform: Lessons from the Past, Prospects for the Future 57, 63 (James A. Morone \& Gary S. Belkin eds., Duke Univ. Press 1994). 
and his wife Bess, to honor Truman for his advocating for national health care legislation at the end of the World War II. ${ }^{9}$

\section{B. The Evolution of Medicare}

Unlike Medicaid, which pays based on means testing and is managed and run by the states, Medicare is federally run, and partially paid through payroll taxes. In particular, Medicare is financed through the Federal Insurance Contributions Act (FICA) for regular employees, and the Self-Employment Contributions Act, for the self-employed. Those who are under the FICA system contribute $1.45 \%$ withholding from their paychecks and employers match with a contribution of $1.45 \%$. The self-employed must pay the entire $2.9 \%$ themselves.

Part A (hospital and nursing home services) ${ }^{10}$ and Part B (physicians' services, home health services, outpatient care, and other health services) ${ }^{11}$ were enacted by the Social Security Amendments of 1965. Part C (which covers health plans handled by private insurers), ${ }^{12}$ was subsequently introduced with the Balanced Budget Act of 1997. Extremely limited prescription drug coverage was added with the Medicare Secondary Payer Act (MSP) of $1980 .{ }^{13}$ Moreover, when originally enacted in 1965, Medicare originally when Medicare had been enacted in 1965, it acted as primary coverage, that would pay toward eligible services before other applicable insurance coverage would pay (the exception being workers compensation). ${ }^{14}$

However, the MSP shifted responsibility of Medicare and subordinated Medicare into becoming secondary coverage to other private coverage..$^{15}$ The

9. Taylor Branch, At CanaAn's Edge: America in the King Years 1965-68, at 272 (Simon \& Schuster 2006).

10. 42 U.S.C. $\S \S 1395 \mathrm{c}-1395 \mathrm{i}-5$.

11. 42 U.S.C. $\S \S 1395 \mathrm{j}-1395 \mathrm{w}-4$.

12. 42 U.S.C. $\$ \S 1395 \mathrm{w}-21-1395 \mathrm{w}-29$.

13. Omnibus Budget Reconciliation Act of 1980, Pub. L. No. 96-499, 94 Stat. 2599.

14. S. REP. No. 404, at $\$ 1862$ (1965), reprinted at 1965 U.S.C.C.A.N. 1965, $2127-28$ ("[N]o payment may be made ... for any item or service for which payment has been made, or can reasonably be expected to be made, under a workman's compensation law or plan of the United States or a State. Any payment ... with respect to any [such] item or service must be conditioned on reimbursement being made to the appropriate trust fund for such payment if any when notice or other information is received that payment for such item or service has been made under such a law or plan.").

15. 42 U.S.C. $\$ 1395 y(b)$; Zinman v. Shalala, 67 F.3d 841, 845 (9th Cir. 1995) (“The transformation of Medicare from the primary payer to the secondary payer with a right of reimbursement reflects the overarching statutory purpose of reducing Medicare costs."). See also Medicare Program, Services Covered under Automobile Medical, No-Fault, or Liability Insurance; Services Furnished to ESRD Beneficiaries Who Are Covered under Employer Group Health Insurance, 48 Fed. Reg. 14802, 14807 (Apr. 5, 1983) (to 
MSP permitted subrogation and recovery of benefits paid by Medicare. ${ }^{16}$ This allowed for Medicare to have a lien for the purpose of recovering reimbursement from a primary coverage. However, because Medicare lacked an effective method of identifying or pursuing cases where its liability should have been secondary, the MSP was amended again in $1986 .{ }^{17}$ Enforcement of the MSP was problematic in its early years, and further revisions were necessary to allow for proper enforcement of its provisions. ${ }^{18}$ Oftentimes, simply attempting to determine when Medicare is secondary can be a complex process. ${ }^{19}$

The Department of Health, Education, and Welfare (the department responsible for Social Security and Medicare) was re-designated the Department of Health and Human Services (HHS), in 1979. ${ }^{20}$ President Bill Clinton attempted to overhaul the Medicare system in 1993-1994 with his health care reform plan: Clinton's plan called the Health Security Act would have required each U.S. citizen and resident alien would have been required to be enrolled in a qualified health plan. ${ }^{21}$ Employers would have been required to cover their employees through Health Maintenance Organizations ("HMOs"), and the bill would have required the creation and regulation of

be codified at 42 C.F.R. pt. 405) ("Congress clearly intended that Medicare not pay first when there is a reasonable expectation that the employer plan will pay as promptly as Medicare. . . Medicare will be primary payer for items and services not covered by the employer plan and will make conditional primary payments if the intermediary or carrier determines that the employer plan will not pay promptly.").

16. United States v. Baxter Int'l, Inc., 345 F.3d 866, 901-02 (11th Cir. 2003).

17. Omnibus Budget Reconciliation Act of 1986, Pub. L. No. 99-509, § 9319, 100 Stat. 1874 (codified at 42 U.S.C. $\S 1395 y(b)(2)(B)(2006)$ ).

18. Jennifer C. Jordan, Medicare Secondary Payer Comes of Age: An Industry Insider's View, EMERGing Issues L. Blog (Oct. 6, 2010, 04:02 PM), http://www.lexisnexis.com/Community/insurancelaw/ blogs/insurancelawblog/archive/2010/10/06/medicare-secondary-payer-comes-of-age-an-industry-insider-sview.aspx ("A historical look at early MSP enforcement reveals years of frustrated efforts by the federal government in overcoming poorly written law. The MSP was written without a notice requirement so that CMS could be placed on notice of a settlement and thus be aware of its recovery right, and what little requirement that was included in the regulations provided no penalty for failure to comply. Then, even in cases where the government became aware of recovery opportunities, it lost several suits in federal court primarily due to technicalities, such as the definition of a self-insured.").

19. See generally Ctrs. for Medicare and Medicaid Serv., Medicare Secondary Payer Manual, Pub. No. 100-05, Ch. 1, 10 (65th rev. ed. 2009), available at http://www.cms.hhs.gov/Manuals/ IOM/itemdetail.asp?filterType $=$ none\&filterByDID=99\&sortByDID $=1$ \&sortOrder=ascending\&itemID $=$ CMS019017\&intNumPerPage $=10$.

20. Dep't of Ed. Org. Act, Pub. L. No. 96-88, § 509, 93 Stat. 695 (1979).

21. H.R. 3600, 103d Cong. (1993-1994). 
regional health care alliances. ${ }^{22}$ However, the plan was opposed by the health care industry in large part, ${ }^{23}$ failed to win proper support and did not pass. ${ }^{24}$

In fact, Medicare would move away from expansion, and succumb to political calls for reduction. ${ }^{25}$ In 1995, led by Speaker of the House Newt Gingrich, Republican leadership in the Congress proposed a drastic restructuring of the program. ${ }^{26} \mathrm{~A}$ high-profile vicious debate with President Clinton and the congressional Democrats ensued, which was considered perhaps the greatest fight in the program's 30-year history. ${ }^{27}$ Although a Republican congressional majority passed a Medicare reform bill in 1995, President Clinton proceeded to promptly veto the bill. ${ }^{28}$ Medicare reform remained deadlocked until two years later, when the Clinton administration would cede to demands for modernization, competition, choice, and market dynamics. ${ }^{29}$ Subsequently, the next change came to compensation payments to providers, which were reduced with the Balanced Budget Act of 1997..$^{30}$

Also in 1997, the State Children's Health Insurance Program (SCHIP) ${ }^{31}$ was brought into existence. This program, which was directed toward the medical needs of children, and resulted in further expansion of taxpayerfunded health insurance coverage. Two years later, the allowable amounts of compensation payments that had been reduced by the 1997 BBA, were then subsequently raised again with the Medicare, Medicaid, and SCHIP Balanced Budget Refinement Act (BBRA) of 1999. ${ }^{32}$ Subsequently, in the Medicare, Medicaid, SCHIP Benefit Improvement and Protection Act of 2000 (BIPA),

22. $I d$.

23. See Michael Wines \& Robert Pear, President Finds Benefits in Defeat on Health Care, N.Y. Times (July 30, 1996), available at http://www.nytimes.com/1996/07/30/us/president-finds-benefits-indefeat-on-health-care.html?src=pm.

24. Ernst \& Young LlP, Industry in Transition: 1999 Health Care Trends Analysis 42-43 (1999). (2003).

25. Jonathan Oberlander, The Politics of Medicare Reform, 60 WASH. \& LEE L. REv. 1095, 1120

26. H.R. 2491, 104th Cong. $\S \S 8000-8708$ (1995).

27. Oberlander, supra note 25.

28. Wines \& Pear, supra note 23.

29. Oberlander, supra note 25.

30. Balanced Budget Act of 1997, Pub. L. No. 105-33, §§ 4711-15,111 Stat. 251, 507-11.

31. Maternal \& Child Health Bureau, Health Res. \& Servs. Admin., U.S. Dep't of Health \& Human Servs., Children's Health Insurance Program Overview, Nat'l Conference of State Legislatures (Jan. 24, 2011, 09:00 PM), http://www.ncsl.org/default.aspx?tabid=14510 (stating that SCHIP derives its statutory authority from Title XXI of the Social Security Act).

32. Consol. Appropriations Act, Pub. L. No. 106-113, 113 Stat. 1501 (1999). 
Congress made other helpful changes, such as providing coverage for some preventive benefits. ${ }^{33}$

Despite these various changes since the enactment of Medicare, the most comprehensive legislative change in the history of Medicare came in $2003 .^{34}$ The Medicare Prescription Drug, Improvement, and Modernization Act $(\mathrm{MMA})^{35}$ mandated the creation of the Office of Medicare Hearings and Appeals (OMHA) ${ }^{36}$ It additionally established substantial prescription drug coverage under Part $\mathrm{D}$, which closed the gaps left by the coverage from the Secondary Payer Act. ${ }^{37}$ The House bill passed with a narrow vote running closely along partisan lines; 216 were for, 215 against, one merely answering present, and three not voting. ${ }^{38}$ Of the 216 in favor, 207 were Republicans; of the 215 against, 195 were Democrats. ${ }^{39}$

Other insurers deemed primary within the meaning of the MSP, are considered responsible reporting entities (RREs). Previously, it was often difficult for the Centers for Medicare and Medicaid Services (CMS) ${ }^{40}$ to identify primary insurers, for purposes of recouping payment. By addressing this flaw, and providing for more efficient mechanisms for Medicare lien recovery, the program would become better able to contain its ever-rising costs by shifting the burden of identification to primary insurers. Under the

33. Medicare, Medicaid, SCHIP Benefit Improvement \& Prot. Act of 2000, Pub. L. No. 106-554, 114 Stat. 2763.

34. Alexander R. Shekhdar, Strategic Choices for Managed Care Plans Under the Modernization Act of 2003, 37 J. HEALTH L. 429 (2004) ("With the inclusion of a prescription drug benefit in the standard Medicare benefits package (referred to as "Part D"), the MMA presents the most dramatic overhaul to the Medicare program in its history. While the prescription drug benefit is without question the most prominent feature of the MMA, the new law also overhauls the managed care component of Medicare, the Medicare + Choice program $(\mathrm{M}+\mathrm{C}$ or Part $\mathrm{C})$, which includes renaming $\mathrm{M}+\mathrm{C}$ to Medicare Advantage. In many ways, the new Part $\mathrm{C}$ may have the most lasting significance of the wide-ranging reforms contained in the MMA. It has the potential to profoundly reshape Medicare by creating vigorous, market-driven alternatives to the traditional fee-for-service Medicare program.") (footnotes omitted).

35. Medicare Prescription Drug, Improvement \& Modernization Act of 2003, Pub. L. No. 108-173, 117 Stat. 2066

36. ExpectMore.gov, Detailed Information on the Office of Medicare Hearings \& Appeals Assessments, http://www.whitehouse.gov/omb/expectmore/detail/10003554.2008.html (last visited Oct. 11, 2010).

37. Omnibus Budget Reconciliation Act of 1980, Pub. L. No. 96-499, 94 Stat. 2599.

38. Office of the Clerk, U.S. House of Representatives, Final Vote Results for Call 332 (June 27, 2003, 02:33 AM), http://clerk.house.gov/evs/2003/roll332.xml.

39. Id.

40. CMS is the agency responsible for administering Medicare. Previously, the agency was known as the Health Care Financing Administration (HCFA), a sub-unit of the Department of Health and Human Services (HHS); subsequently, HCFA was renamed as the CMS. 
Medicare, Medicaid, and SCHIP Extension Act of 2007 (MMSEA), ${ }^{41}$ RREs are now required to (1) register with Medicare; and (2) must electronically report information to $\mathrm{CMS} .{ }^{42} \mathrm{CMS}$ can use this information to track, and recover health expenses it incurred, but that an RRE may be responsible for paying. ${ }^{43}$

Parts II-V of this Essay will describe Medicare Parts A-D respectively. Part VI will describe the general appellate process. The Essay will conclude with Part VII discussing the Level 3 Appellate Process for which OMHA is responsible.

\section{Part A: Original Medicare/Hospital Insurance}

Part A Medicare refers to the hospital insurance program authorized under Part A of Title XVIII of the Medicare Act. ${ }^{44}$ Part A covers inpatient hospital care, skilled-nursing facility care, hospice care and home health care. ${ }^{45}$ Medicare also covers up to 90 days of hospital care per illness occurrence (benefit period) subject to any deductibles and coinsurance payments. ${ }^{46}$ A benefit period or illness occurrence is technically referred to as a "spell of illness," in Title 42 United States Code section 1395x, which is defined as follows:

The term "spell of illness" with respect to any individual means a period of consecutive days-

(1) beginning with the first day (not included in a previous spell of illness) (A) on which such individual is furnished inpatient hospital services, inpatient critical access hospital services or extended care services, and (B) which occurs in a month for which he is entitled to benefits under part $\mathrm{A}$ of this subchapter, and

(2) ending with the close of the first period of 60 consecutive days thereafter on each of which he is neither an inpatient of a hospital or critical access hospital nor an inpatient of a facility described in section 1395i-3(a)(1) of this title or subsection (y)(1) of this section.

Each beneficiary also receives 60 days of exhaustible lifetime hospital care coverage; the 60-day additional amount is a reserve amount that is not per occurrence, but rather a maximum amount that once exhausted can never be

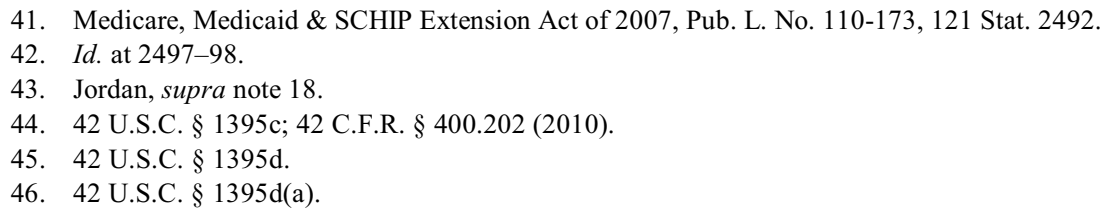


extended again. ${ }^{47}$ There is a first-time deductible per benefit period, ${ }^{48}$ a perday coinsurance amount equal to one-fourth of the applicable deductible running from the 61 st through the 90 th day, ${ }^{49}$ a daily coinsurance amount for each lifetime reserve day equal to one-half the applicable deductible, and a three-pint blood deductible per benefit period. ${ }^{50}$ Post-hospital extended care is provided up to 100 days per benefit period, ${ }^{51}$ and inpatient psychiatric services are provided up to 190 days per lifetime. ${ }^{52}$ A list of the covered services is available at 42 C.F.R. $\S \S 409.10-409.19$.

Part A Medicare provides some coverage for skilled nursing-facility care (SNF).$^{53} \mathrm{~A}$ beneficiary must be to a Medicare-certified SNF within 30 days of a covered hospital stay of three or more days, or more than 30 days if SNF treatment would not have been medically appropriate within 30 days of discharge from the hospital..$^{54}$ A physician must certify need..$^{55}$ As a "practical matter," a requirement and delivery of daily skilled-nursing or skilledrehabilitation services, can only be provided on an inpatient basis at an SNF, and must have been required to treat a condition that was the reason, in whole or in part, for the prior hospital admission or stay. ${ }^{56}$

Additionally, the required services must be for a condition for which the beneficiary was treated as a hospital inpatient or that arisen in the course of covered care.$^{57}$ If all of the conditions have been met, then the services are covered in full for the first 20 days, and a daily coinsurance amount equal to one-eighth the hospital deductible applies for the next 80 days. ${ }^{58} \mathrm{~A}$ list of the covered SNF services is available at Title 42, Code of Federal Regulations section 409.20. A list of services that are considered skilled is found at Title 42, Code of Federal Regulations sections 409.20-409.35.

Home health care services are covered as well. ${ }^{59}$ In particular, if a beneficiary is homebound, under a physician's care and needs intermittent skilled-nursing care, physical therapy or speech-pathology services, then he

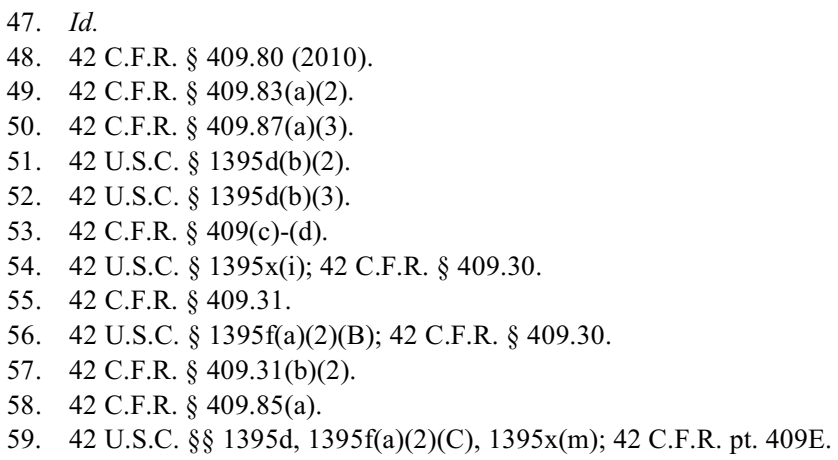


or she can receive an unlimited number of home health visits from a Medicare-certified home health agency without requiring deductibles or coinsurance payments. ${ }^{60}$ Part-time or intermittent services means "skilled nursing and home health aide services furnished any number of days per week as long as they are furnished (combined) less than 8 hours each day and 28 or fewer hours each week (or, subject to review on a case-by-case basis as to the need for care, less than 8 hours each day and 35 or fewer hours per week)." ${ }^{, 61}$ In order to be qualified, the home health care services must be furnished in the beneficiary's home, unless impractical, must be provided by a Medicare certified agency, and a physician must establish and periodically review the treatment plan. ${ }^{62}$

Hospice care is also covered. ${ }^{63}$ If a beneficiary's physician or the hospice director certifies that the beneficiary is terminally ill based on clinical judgment regarding the normal course of the individual's illness, then the beneficiary may receive unlimited hospice care (two periods of 90 days, and unlimited number of subsequent periods of 60 days) from a Medicare approved program. ${ }^{64}$ Terminally ill is considered a condition in which the beneficiary's life expectancy is six months or less based on the normal course of the illness, but should the beneficiary survive past six months, he or she may elect to still remain under hospice care. ${ }^{65}$ Hospice care is defined as any service that provides care for the beneficiary rather than attempting to cure the illness or condition. ${ }^{66} \mathrm{~A}$ list of the covered hospice care services is found at 42 C.F.R. $\S \S 418.80-418.100$.

\section{Part B: Original Medicare/Supplementary Medical Insurance}

Part B Medicare refers to the supplementary medical insurance program authorized under Part B of [T]itle XVIII of the Act. ${ }^{67}$ Part B supplements Part A by covering other medical services. A list of services typically covered by Part B is found at Title 42 United States Code $\S \S 1395 \mathrm{k}$ and $1395 \mathrm{x}$ and at Title 42 Code of Federal Regulations part 410, subpart B. Such services covered under Part B include physician services, such as consultation,

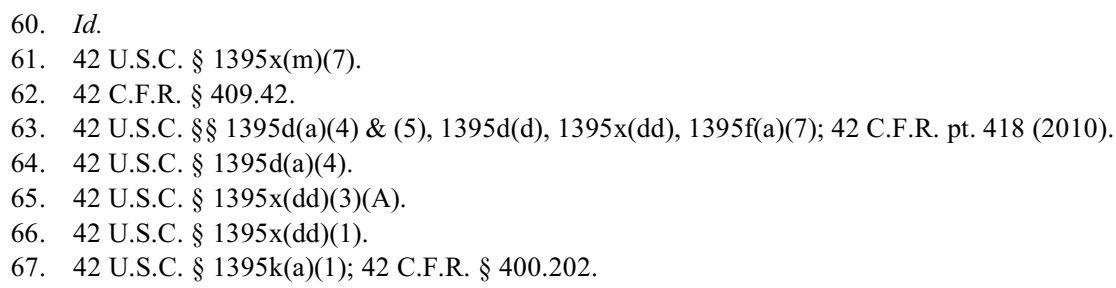


diagnosis and surgery, diagnostic X-ray tests, diagnostic laboratory tests and other diagnostic tests, X-ray therapy, radium therapy and radioactive isotope therapy, rental or purchase of durable medical equipment, prosthetic devices, leg, arm, back and neck braces and artificial legs, arms and eyes, ambulance services, outpatient rehabilitation and hospital diagnostic services furnished incident to physician services, outpatient physical therapy, occupational therapy and speech pathology, and so forth. ${ }^{68}$

Therapy services may be subject to annual monetary caps. Beneficiaries may also be covered for home health services with no deductible, regardless of whether they have used up 100 Part A visits. ${ }^{69}$ Preventive screening annual mammograms are covered. ${ }^{70}$ Part B covers other preventive measures such a periodic screening pap smears and pelvic exams. ${ }^{71}$ An initial physical exam is paid for and occurs within six months of the beginning of Medicare Part B coverage. ${ }^{72}$ Diabetes screening tests, cardiovascular blood screening tests, prostate cancer screening, periodic colorectal cancer screening tests, and glaucoma screening for those with a family history of glaucoma or diabetes, is covered. ${ }^{73}$ By contrast, routine physical exams and checkups; annual eye examinations; eyeglasses; hearing aids; immunizations other than pneumococcal, hepatitis B and influenza vaccines; orthopedic shoes and foot care; dental services and cosmetic surgery are expressly excluded from Part B coverage. ${ }^{74}$ Other exclusions are found at Title 42 United States Code $\S 1395 y(a)$.

Often the amount Medicare is willing to cover differs from the amounts actually charged and the beneficiaries must pay the difference, but liability may be limited by statute if there has not been an assignment of benefits. ${ }^{75}$ The amount of reimbursement Medicare allows in some cases is 80 percent for certain home health services, medical and other health services, and any other services described in Title 42 United States Code $\S 1395 \mathrm{k} .{ }^{76}$ Part B coverage pays the lower of actual, customary charge or the prevailing charge. ${ }^{77}$ The feeschedule amount is derived from a combination of the relative value for the

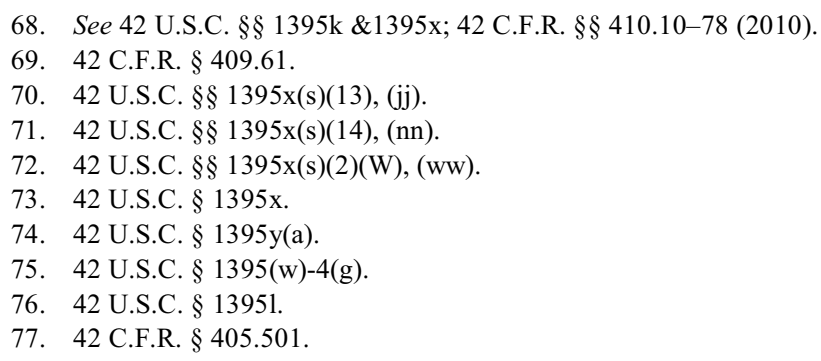


service, a factor of conversion, and a geographic adjustment factor. ${ }^{78}$ If benefits have been assigned, then the provider may pursue and collect payment directly from Medicare, but cannot pursue the entire difference; the provider may only collect any unpaid deductible, not the actual charged amount. ${ }^{79}$ Without an assignment, the physician may not charge in excess of 115 percent of the Medicare approved amount. ${ }^{80}$

\section{Part C: Medicare Advantage Plans}

Part C Medicare, refers to the choice of Medicare benefits through Medicare Advantage (MA) plans authorized under Part C of the title XVIII of the Act. ${ }^{81}$ The policies of carriers that offer MA plans are regulated by statute. ${ }^{82}$ The program was originally named Medicare+Choice, which was replaced by MA, with the passage of the Medicare Prescription Drug, Improvement, and Modernization Act of 2003. ${ }^{83}$ The MA program is a competitive alternative to the original Medicare fee-for-service and Medicare risk health maintenance organizations (HMOs). The arrangement is usually pursuant to a contract or policy agreement with an MA organization, which must typically meet state and federal requirements. Different options include: HMOs, Special Needs Plans (available to certain beneficiaries with special needs), preferred provider organizations (PPOs), provider sponsored organizations (PSOs) (limiting use of providers to those in the plan network), medical savings account (MSA) plans which are private health-insurance policies with high yearly deductibles, private fee-for-service plans for which Medicare pays part of the cost, and in which all providers within the network must agree to serve the Medicare beneficiary for the fee-for-service plan payment amount. ${ }^{84}$

As of 2007 and onwards, open enrollment annually takes place November 15 through December 31 for coverage starting the following year. ${ }^{85}$ Enrollment may be changed between January 1 and March $31 .{ }^{86}$ An MA plan

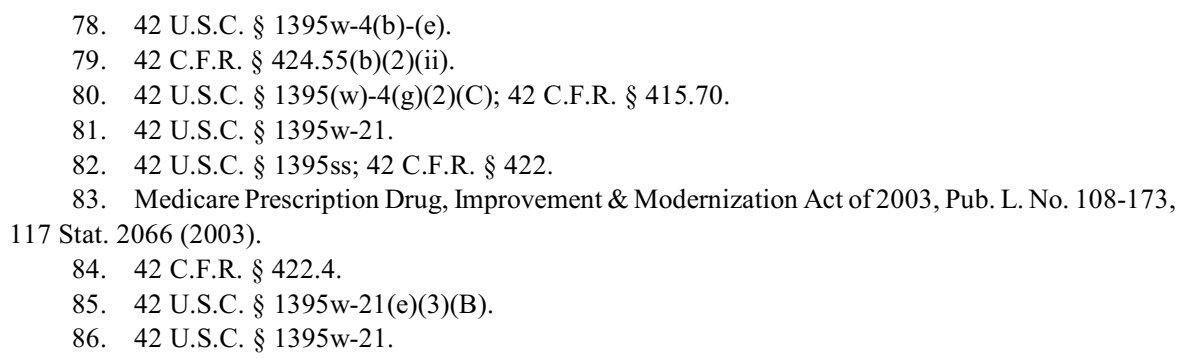


must provide all for coverage of all Medicare-covered services, except hospice services. ${ }^{87}$ The MA organization must among other plans, also offer at least one MA-prescription drug plan providing qualified Part D prescription drug coverage. MA plan may also offer supplemental benefits. ${ }^{88}$

Often, those enrolled in MA plans are limited to the physicians available in the MA plan's network and must designate a primary care physician (PCP). Further care often is by referral from the PCP. However if the certain specialty care is not available or inadequate, then the MA plan must provide out of network specialty care. ${ }^{89}$ All medically necessary services must be provided to MA plan participants 24 hours a day, seven days a week..$^{90}$

If a member moves to a skilled nursing home facility (SNF) after a hospital stay, regardless of whether the MA plan has a contract with that facility, the MA plan must pay reimbursement as long as the facility is willing to accept it. ${ }^{91}$ Such facilities include the facility the member resided at prior to hospitalization, the facility where the member's spouse resides, and a facility located in the continuing care retirement community where the member resided before hospitalization. ${ }^{92}$

\section{Part D: Prescription Drug Plans}

Part D Medicare, means the voluntary prescription drug benefit program authorized under Part D of Title XVIII of the Act. ${ }^{93}$ An individual is eligible for Part D if he or she is entitled to Medicare benefits under Part A or enrolled in Medicare Part B, and lives in a defined service area of a Part D plan. ${ }^{94}$ Historically, a voluntary prescription drug benefit program had not been a part of Medicare, and this left a gap that was finally filled with the passage of the Medicare Prescription Drug, Improvement, and Modernization Act in 2006. ${ }^{95}$ Private insurers administer the plans, and although participation is technically voluntary, a one percent premium penalty may be assessed for each month a person who is eligible, and fails to carry "creditable coverage." 96

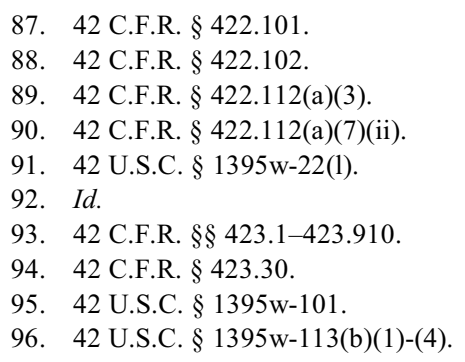


Those enrolled in an MA plan already have access to a prescription to a prescription drug plan (PDP) through his or her MA plan. ${ }^{97}$ Those not in an MA plan can obtain coverage through Part D. ${ }^{98}$ Once enrolled in a PDP, beneficiaries can change plans only once per year, from November 15 though December $31 .{ }^{99} \mathrm{CMS}$ makes subsidy payments to encourage the continuation of employer-sponsored retiree prescription drug plans, ${ }^{100}$ though it cannot negotiate with pharmaceutical companies for lower drug prices ${ }^{101}$ and cannot re-import drugs. ${ }^{102}$

Standard plans charge varying premium amounts, have different cost sharing requirements and typically include a gap in coverage, for which there may be no insurance protection. Benefits and prices may widely vary and are not uniform: companies are free to vary the benefit as long as it remains "actuarially equivalent" to a CMS standard. ${ }^{103}$ Also, prices may vary by region and by insurer. Low-income individuals and those with limited assets may be eligible for a low-income subsidy (LIS) and have lower out-of-pocket costs. ${ }^{104}$ Medicare beneficiaries who also have Medicaid prescription drug coverage must enroll in a Medicare D plan in order to access prescription drug coverage. $^{105}$

\section{The Appeals Process}

OMHA is responsible for hearing Medicare appeals at the administrative law judge level, which is the third level of Medicare claims appeals. ${ }^{106}$ OMHA ensures that Medicare beneficiaries who are dissatisfied with the initial decisions about their benefits or eligibility can appeal and exercise their right

97. 42 C.F.R. $\S 422.66$.

98. 42 C.F.R. $\S 423.30$.

99. 42 C.F.R. $\S 423.38$.

100. Uwe E. Reinhardt, Is 'ObamaCare' Destroying Wealth, N.Y.Tiмes.сом (Apr. 2, 2010, 7:01 AM), http://economix.blogs.nytimes.com/2010/04/02/is-obamacare-destroying-corporate-wealth/.

101. 42 U.S.C. $\S 1395 \mathrm{w}-111(\mathrm{i})$.

102. 21 U.S.C. $\S 381(d)$.

103. 42 C.F.R. $\S 423.104$.

104. 42 C.F.R. $\S 423.904$.

105. 42 C.F.R. $\S 423.906$.

106. ExpectMore.gov, supra note 36 ("OMHA hears cases at the third level of appeal, the Administrative Law Judge (ALJ) level. On an annual basis, carriers and intermediaries process approximately 1.2 billion claims for Medicare payment. Of this total, payment is denied for approximately $10 \%$. Beneficiaries, providers, and suppliers have the right to appeal denied claims. Appeal claims submitted for Medicare items and services are denied for a variety of reasons. The most common reasons for denying a claim are: the services provided were determined to be unnecessary for the beneficiary; Medicare did not cover the services; or the beneficiary was not eligible for services."). 
to a hearing in front of an Administrative Law Judge (ALJ). ${ }^{107}$ Appropriations for the OMHA were $\$ 71,147,000$ in 2010 ; a recent Senate Report has indicated that $\$ 77,798,000$ is recommended for 2011 , and this amount includes increased funding for ALJ teams, so that OMHA can properly handle its workload. ${ }^{108}$ When an unfavorable Medicare determination is made, there are five types of appeals that an appellant may use, each type corresponding to a level. The levels progress numerically from lower to higher, and the appellant must exhaust each level in turn before proceeding to the next level. ${ }^{109}$ The process begins with an initial determination that has been made regarding a Medicare claim, and notice being provided to the claimant. ${ }^{110}$ If represented, unless the government's position is justified, the appellant's attorney is entitled to attorney's fees if the appellant prevails on appeal. ${ }^{11}$

Typically, after the initial decision is made either the contractor, ${ }^{112}$ the Medicare Advantage Plan, or the drug plan will advise what steps must be taken to file the Level 1 appeal. ${ }^{113}$ The steps vary depending on which Medicare Part is involved. ${ }^{114}$ The first level is a redetermination when Parts A \& B coverage are involved. ${ }^{115}$ The same Medicare contractor, who made the original decision, will take a second look at the claim, but a different individual will be assigned to review it. This redetermination is a new and independent review. ${ }^{116}$

If Part $\mathrm{C}$ is involved, then the first level is reconsideration. ${ }^{117}$ Reconsideration must be requested within 60 days of the decision. ${ }^{118}$ A new decision must be rendered within 30 days of the appeal ${ }^{119}$ by the Medicare Advantage Plan if it is a request for a service, ${ }^{120}$ or 60 days if it involves a

107. ExpectMore.gov, supra note 36.

108. S. REP. No. 243, at 145 (2010).

109. Therefore, the appellant must go through at least two levels of appeals prior to reaching the third level, which involves the OMHA and an ALJ.

110. 42 C.F.R. $\S 405.803$.

111. Equal Access to Justice Act, Pub. L. 96-481, 94 Stat. 2321 (1980); 5 U.S.C. $\S 504$ (2006); 28 U.S.C. $\$ 2412$ (2006).

112. "Contractors refer to carriers, fiscal intermediaries, and other entities that contract with CMS to review and adjudicate claims for Medicare services." 42 C.F.R. $\S 405.201$ (b).

113. See Alfred J. Chiplin, A Practical Guide to Medicare Hearings and Appeals, 34 ReAl Prop. Prob. \& TR. J. 403, 432, 435, 438 (1999).

114. Id.

115. 42 C.F.R. $\S \S 405.940-405.958$.

116. 42 C.F.R. $\S 405.948$.

117. 42 C.F.R. $\S 422.562$.

118. 42 C.F.R. $\S 422.582$.

119. 42 C.F.R. $\S 422.590(a)$.

120. 42 C.F.R. $\S 422.618(a)(1)$. 
payment. ${ }^{121}$ If the reconsideration takes longer than the deadline, or if the reconsideration decision is unfavorable, the Medicare Advantage plan must forward the appeal automatically to an outside entity for a second level review. ${ }^{122}$ If Part D is involved, then the first level is a redetermination, and the request for appeal must be submitted to the drug plan within 60 days. ${ }^{123} \mathrm{~A}$ decision must be rendered by the drug plan in 7 days, or the drug plan must submit the appeal automatically to the second level. ${ }^{124}$ Likewise, an unfavorable untimely redetermination must also be forwarded automatically to Level 2. ${ }^{125}$

With a Level 2 appeal involving Parts A \& B, an appellant must appeal the redetermination decision within 180 days. ${ }^{126}$ The appellant must follow the procedure outlined on the redetermination notice. Additionally, the appellant must include the reason for disagreement with the initial determination and redetermination and forward any helpful or applicable information with the request. It is also possible to obtain an expedited redetermination, resulting in an answer within 72 hours. ${ }^{127}$ It is important to submit all evidence at this stage, because an appellant may have to show good cause for introducing any new evidence during Level 3 of the process that was never submitted at the second level. If appealed, a Qualified Independent Contractor (QIC), retained by CMS, will conduct what is called a reconsideration, which is usually conducted on-the-record. If the QIC makes an unfavorable determination and the amount in dispute is $\$ 100$ or more, then the notice will indicate how to appeal the matter to the OMHA-Level $3 .{ }^{128}$ If a decision is not rendered within 60 days, ${ }^{129}$ then the appellant has a right to escalate the matter to a Level 3 appeal to be heard before the OMHA.

121. 42 C.F.R. $\S 422.618(a)(2)$.

122. 42 C.F.R. $\S 422.590(b)$.

123. 42 C.F.R. $\S 423.582(\mathrm{~b})$.

124. 42 C.F.R. § 423.568(h) ("If the Part D plan sponsor fails to notify the enrollee of its determination in the appropriate timeframe under paragraphs (b) or (c) of this section, the failure constitutes an adverse coverage determination, and the plan sponsor must forward the enrollee's request to the IRE within 24 hours of the expiration of the adjudication timeframe.").

125. 42 C.F.R. $\S 423.590$ (c) ("If the Part D plan sponsor fails to provide the enrollee with a redetermination within the timeframes specified in paragraphs (a) or (b) of this section, the failure constitutes an adverse redetermination decision, and the Part D plan sponsor must forward the enrollee's request to the IRE within 24 hours of the expiration of the adjudication timeframe.").

126. 42 U.S.C. $\S 1395 \mathrm{ff}(\mathrm{b})(1)(\mathrm{D})$.

127. 42 U.S.C. $\$ 1395 f f(c)(3)(C)(i i i) ; 42$ C.F.R. § 478.18(c).

128. 42 U.S.C. $\$ 1395 \mathrm{ff}(\mathrm{b}) ; 42$ C.F.R. $\S 405.904$.

129. 42 U.S.C. $§ 1395 \mathrm{ff}(\mathrm{c})(3)(\mathrm{C})(\mathrm{i}) ; 42$ C.F.R. $\S 405.970(\mathrm{a})$. 
In a Part C Level 2 appeal, an Independent Review Entity (IRE) conducts the review process of the appeal. ${ }^{130}$ This entity is retained by CMS, much like how a QIC is retained with Parts A and B. ${ }^{131}$ This appeal is called a reconsidered determination. ${ }^{132}$ After the IRE has reviewed the case, the appellant will receive a copy of the decision. ${ }^{133}$ The IRE decision will contain information about the process of further appeal. ${ }^{134}$ If the appellant is dissatisfied with the reconsidered determination, the amount in controversy meets a $\$ 100$ minimum threshold, ${ }^{135}$ and he or she files an appeal within 60 days of the reconsidered determination, then the matter may go before the OMHA for a Level 3 appeal. ${ }^{136}$ It is possible to combine claims to satisfy the $\$ 100$ threshold. ${ }^{137}$ A Part D Level 2 appeal goes through the same process as a Part $\mathrm{C}$ appeal, but the reconsidered determination must be completed by the IRE within seven days of the request for appeal. ${ }^{138}$ The same deadline and amount in controversy must be observed to obtain a Level 3 appeal before the OMHA. Like Parts A and B, a Part D Level 2 appeal, can be expedited, resulting in a response within 72 hours. ${ }^{139}$

The third level of appeal involves review before an ALJ with the OMHA. This portion of the process is discussed in Part VII of this Essay. If the appellant is not satisfied with the determination at the Level 3 appeal, then he or she must forward a written request to the Medicare Appeals Council (MAC) within 60 days of receiving the ALJ's decision. ${ }^{140}$ The amount in controversy must satisfy at least the $\$ 100$ threshold in all cases. ${ }^{141}$ To proceed with a Level 4 appeal, detailed written information about the claim must be

130. 42 C.F.R. $\S \S 422.592-422.596$.

131. See generally Ctrs. for Medicare and Medicaid Serv., Medicare Managed Care Manual, Pub. No. 100-16, Ch. 13, § 10.1 (95th rev. ed. 2011), available at http://www.cms.gov/ manuals/iom/itemdetail.asp?itemid $=$ CMS019326.

132. 42 C.F.R. $\S \S 422.592-422.596$.

133. 42 C.F.R. $\S 422.594$.

134. $I d$.

135. 42 U.S.C. $\S 1395 f f(b)(1)(A) ; 42$ C.F.R. $\S 405.1000$.

136. 42 C.F.R. $\S 422.602$.

137. See, e.g., 422 C.F.R. 422.600 ("The amount remaining in controversy, which can include any combination of Part A and Part B services, is computed in accordance with part 405 of this chapter.").

138. 42 C.F.R. $\S \S 423.590-423.600$.

139. 42 C.F.R. $\S 423.590$ (d) (“A Part D plan sponsor that approves a request for expedited redetermination must complete its redetermination and give the enrollee (and the prescribing physician or other prescriber involved, as appropriate), notice of its decision as expeditiously as the enrollee's health condition requires but no later than 72 hours after receiving the request.").

140. 42 C.F.R. $\S 405.1102$ (a).

141. 42 C.F.R. $\S 478.44$. 
provided, as well as the date of the ALJ decision or dismissal, and any additional evidence to be submitted. ${ }^{142}$

Copies of the request must be furnished to all other involved parties. The Level 4 appeal request must be mailed to the MAC, which is located in Washington, DC. All Level 4 appeals are on-the-record, ${ }^{143}$ unless the case raises important issues of policy, law or facts that cannot be decided on-therecord. The MAC is part of HHS, but is independent of the OMHA and the ALJs. The MAC decision should be rendered within 90 days. ${ }^{144}$

At the fifth level of appeal, if after exhausting all of these administrative remedies, the appellant is still unable to obtain a satisfactory resolution, the appellant may proceed to institute civil litigation, by filing a lawsuit with the local federal District Court. The amount in controversy must meet a threshold of $\$ 2,000 .{ }^{145}$ Different claims may be aggregated to satisfy the threshold. ${ }^{146}$ The appellant must file the complaint with the federal court no later than 60 days from the date of the MAC decision. ${ }^{147}$ It is important to note that the OMHA is only involved at the Level 3 appeals stage, and not any other level of the appeals process.

\section{OMHA AND THE THIRD LEVEL OF REVIEW}

As previously discussed in Part VI of this Essay, if the appellant is dissatisfied with the decision of his or her Level 2 appeal (which is considered a reconsideration in Parts A \& B/Original Medicare, and D/Prescription Drug Plan, and a reconsidered determination in Part C/Medicare Advantage), then he or she can proceed to request a hearing before an OMHA ALJ. ${ }^{148}$ The amount in controversy must meet a $\$ 100$ threshold, although different claims may be aggregated to achieve the minimum amount. ${ }^{149}$ The appellant must forward the written request to the local OMHA Field Office specified in the reconsideration or the reconsideration determination. The appeal must be filed within 60 days of the Level 2 decision. ${ }^{150}$ If an appellant is late with filing a Level 3 appeal, he or she must provide good cause, and request that the ALJ

142. 42 C.F.R. $\S 405.1122$.

143. 42 C.F.R. $\S 405.1120$.

144. 42 C.F.R. $\S 405.1100(c)$.

145. 42 C.F.R. $\S 478.46$.

146. 42 C.F.R. $\S 13935 \mathrm{ff}(\mathrm{b})(1)(\mathrm{E})(\mathrm{ii})$

147. 42 C.F.R. $\S 405.1130$.

148. Parts A \& B: 42 C.F.R. 405.1000. Part C: 42 C.F.R. 422.602 . Part D: 42 C.F.R. 423.2014.

149. 42 U.S.C. $\S 13935 f f(b)(1)(E)(i)-(i i i) ; 42$ C.F.R. $\S 405.1006$.

150. 42 C.F.R. $\S 405.1002(a)(1)$. 
extend the deadline. If no good cause is provided, the ALJ may deny the extension, which would thus end the appeal.

An OMHA ALJ will review the appeal request and claim, within a 90-day period. ${ }^{151}$ The ALJ will set the date, time, and place for the hearing. Hearings are generally held by video-teleconference (VTC), ${ }^{152}$ as there are four field offices $^{153}$ for the hundreds of VTC sites nationwide. Telephone hearings may also be utilized as the circumstances require. An appellant may request an inperson hearing as well. ${ }^{154}$ Good cause must be shown, and the ALJ and Managing ALJ must concur. ${ }^{155}$ Thus, in-person hearings are only to be scheduled by the ALJ, when special circumstances warrant. ${ }^{156}$ A Notice of Hearing with the date, time and location, will be sent to the appellant twenty days prior to the hearing. If the hearing date and time is inconvenient, the appellant may request to reschedule, but the request will only be granted on good cause. ${ }^{157}$

This hearing gives the appellant the opportunity to present his or her appeal to an ALJ, who will independently review the facts of his or her appeal. CMS may participate in the ALJ hearing, with the right to submit evidence. However, if the appellant is unrepresented, CMS may not examine witnesses, or cross-examine witnesses. The ALJ is not bound by any less formal policy manuals and directives ${ }^{158}$ but if the ALJ elects not to follow a policy, he or she must explain why in the decision. ${ }^{159}$ If an appellant wishes to submit evidence for review, they must do so, within 10 days of the Notice of Hearing. ${ }^{160}$

The ALJ will take testimony, and after reviewing the testimonial, documentary, and any physical evidence, ${ }^{161}$ renders a decision. Because the proceeding is administrative, the ALJ is not strictly bound by a trial court's

151. 42 C.F.R. $\S 405.1016$

152. 42 C.F.R. $\S 405.1000$

153. Arlington, Virginia, Cleveland, Ohio, Irvine, California, and Miami, Florida

154. Requesting an in-person hearing, waives the 90 -day time requirement for holding the hearing.

155. 42 C.F.R. $\$ 405.1020$.

156. 42 C.F.R. $\S 405.1020(i)(5)$.

157. 42 C.F.R. $\S 405.1020(\mathrm{e})(4)$

158. These policies, practices and decisions, govern day-to-day administration of Medicare. These may be found in the Commerce Clearing House $(\mathrm{CCH})$ Medicare and Medicaid Guide. The Guide can be obtained from the relevant agency or on the internet. Possible ways to obtain the policies and manuals would be through discovery, or a Freedom of Information Act (FOIA) request.

159. 42 C.F.R. $\S 405.1046$.

160. 42 C.F.R. $\S 405.1018$

161. 42 C.F.R. $\S 405.1036$. 
procedural or evidence rules. ${ }^{162}$ If the evidence is submitted at the day of the hearing, it will be excluded if the ALJ finds that there was no good cause for not submitting the evidence sooner. ${ }^{163}$ While the party is entitled to a full hearing that comports with due process, the appellant may waive this right. The ALJ may decide a case "on-the-record" if a party elects to forego a formal hearing. ${ }^{164}$ Additionally, if the documentary evidence supports a finding fully favorable to the appellant, then the ALJ may issue a decision on-the-record, granting relief requested outright. ${ }^{165}$

OMHA is not only responsible for Level 3 appeals, but also Medicare entitlement appeals - these are appeals from decisions of the SSA that an applicant is not entitled to be a beneficiary of the Medicare program. ${ }^{166}$ Qualifications and eligibility are found at Title 42 United States Code section 426 and Title 42 Code of Federal Regulations part 406. OMHA also handles Part B premium appeals - appeals involving determination of a beneficiary's Income Related Monthly Adjustment Amount (IRMAA), which determines a Medicare beneficiary's total monthly Part B insurance premium. ${ }^{167}$

\section{CONCLUSION}

This Essay has only covered a brief overview of Medicare law, and as has been demonstrated, this body of law is a complex one, driven by numerous statutes as well as administrative rules. It is not inconceivable that the complexity of these rules, may lead to errors, and that is what the appellate process is for. Sometimes Medicare administrators and providers may make proper decisions regarding coverage and payments; sometimes, a Medicare claimant may be forced to pay for services that should have been covered. The Medicare appellate process offers Medicare claimants, due process, and an opportunity to seek further review of prior decisions for correctness. OMHA stands ready to serve as the third level of review, which is truly a critical stage in the process. The function of OMHA fills a critical necessity, and its continued operation has served to help many claimants who are seeking a fair opportunity to obtain redress, and a proper independent review. If problems are necessarily properly handled before OMHA, appeals are diverted from

162. Id.

163. 42 C.F.R. $\S 405.1030$.

164. 42 C.F.R. $\S 405.1038$.

165. Id.

166. 42 C.F.R. $\S 405.904$.

167. 20 C.F.R. $\S 418.1350$. 
necessarily proceeding to the MAC or the federal court system, reducing overall congestion in the courts. 